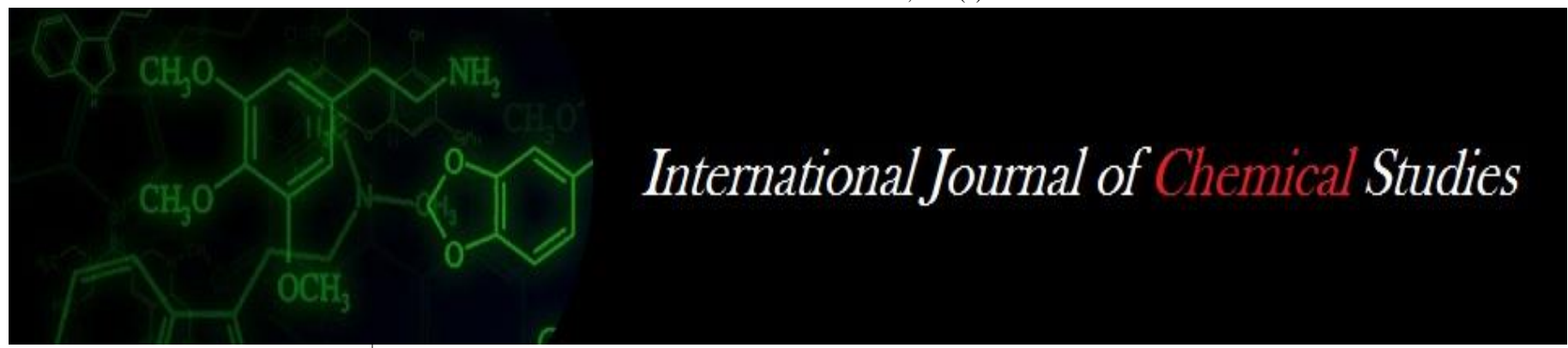

P-ISSN: 2349-8528

E-ISSN: 2321-4902

www.chemijournal.com

IJCS 2020; SP-8(4): 484-488

(C) 2020 IJCS

Received: 28-05-2020

Accepted: 30-06-2020

S Shenbagavalli

Dept. of Soil Science and

Agricultural Chemistry, AC\&RI,

Killikulam, Tamil Nadu, India

T Prabhu

Krishi Vidyan Kendra,

Nagercoil, Tamil Nadu, India

S Ponmani

Mother Therasa Agricultural

College, Pudukottai,

Tamil Nadu, India

\section{Development of fishwaste compost and its effect on quality of soil and crop}

\section{S Shenbagavalli, T Prabhu and S Ponmani}

DOI: https://doi.org/10.22271/chemi.2020.v8.i4h.10331

\begin{abstract}
The main objective of this research was production of compost from fish waste generated from the seafood processing industries at Tuticorin district, Tamilnadu and examine the effect of fishwaste compost on crop and soil quality. The fish waste was acidic in $\mathrm{pH}(6.1)$ with $\mathrm{EC}$ of $3.8 \mathrm{dS} / \mathrm{m}$. The total NPK content of fish waste is $10.17 \%, 0.20 \%, 0.74 \%$ respectively. It has an appreciable amount of organic carbon $46.22 \%$ and secondary nutrients calcium $(1.86 \%)$ and magnesium $(0.15 \%)$ respectively. Fish waste was composted with saw dust under the windrow method of composting and analysed. After composting, fish waste compost (FWC) was neutral in $\mathrm{pH}(7.1)$ with low soluble salts $(\mathrm{EC}=0.38$ $\mathrm{dS} / \mathrm{m})$. It had a considerable amount of $\mathrm{N}(1.6 \%), \mathrm{P}(0.16 \%)$ and $\mathrm{K}(0.21 \%)$. A pot study conducted on blackgram comprising of different doses of fishwaste compost $(0,1,2,3,4,5$ t/ha) along with recommended dose of fertilizer (RDF). Among the different treatments, application of FWC @ 4t/ha enhanced the growth and yield of black gram and improve the soil quality. From the study, it is evident that fishwaste compost can play a significant role in enhancing the soil properties and performance of blackgram invariant of dose applied.
\end{abstract}

Keywords: Fish waste compost, blackgram, nutrient content, yield

\section{Introduction}

In India, many restaurants specialize in sliced raw fish, and large amounts (approximately $2100 \mathrm{t} /$ day) of fish waste are being generated every day (Kinnunen et al., 2005) ${ }^{[3]}$. These wastes are dumped in the vicinity of the seafood processing plants causing environmental pollution. The waste generated by processing fish, crab and shrimp amount to $30 \%$ to $60 \%$, 75- $85 \%$ and $40-80 \%$ respectively (Kinnunen et al., 2005) ${ }^{[3]}$. Hence, ways and means of utilizing these wastes for productive purposes need to be examined.

Direct use of fish waste for land manuring has been discouraged primarily due to the obnoxious odour of putrefied fish. But fish manure contains NPK and micronutrients for plant growth. (Chand et al., 2006) ${ }^{[1]}$. Amruta et al., $2015^{[5]}$ observed an enhanced rhizome yield of $28.6 \mathrm{t} / \mathrm{ha}$ in turmeric when applying compost with fertilizer which was $21.6 \%$ higher over the control plot. Shewry and Holford, (2002) ${ }^{[4]}$ recorded higher growth and yield of cumin and blackgram with the application of compost from seafood processing unit waste. In this context, fish waste samples were collected and composted for evaluation on crop performance and soil quality.

\section{Materials and Methods}

\section{Collection and Characterization of Fish wastes}

Fish wastes were collected from the seafood processing unit, Thoothukudi District, Tamil Nadu, India which contained different portions of fish viz. head, tail, shells, intestine and fins and also dead fishes. The collected fish wastes were cleaned and washed with water to remove dirt and slick. The sample was oven dried at $60^{\circ} \mathrm{C}$ and powdered into fine particles using pestle and mortar. It was sieved using a sieve with $0.2 \mathrm{~mm}$ and stored for further analysis. The aqueous extracts (substrate/water 1:5 v/v) were used to determine the $\mathrm{pH}$, electrical conductivity. After acid digestion with $\mathrm{H}_{2} \mathrm{SO}_{4}$ and $\mathrm{H}_{2} \mathrm{O}_{2} 30 \%$, Ca and $\mathrm{Mg}$ levels were determined by atomic absorption and $\mathrm{Na}$ and $\mathrm{K}$ by emission. Levels of $\mathrm{P}$ were analysed using colorimetry (Chapman and Pratt, 1984). The C: N ratio of the compost were measured by the method followed by (Kinnunenet al., 2005) ${ }^{[3]}$.
Corresponding Author: S Shenbagavalli

Dept. of Soil Science and Agricultural Chemistry, AC\&RI Killikulam, Tamil Nadu, India 
Moisture was determined by drying the samples in the oven at $105{ }^{\circ} \mathrm{C}$ to constant weight (Egan et al., 1997) ${ }^{[2]}$. All parameters were determined in triplicate and the data shown are mean values. The characteristics of fish waste are presented in Table. 1 .

\section{Composting of Fish waste}

A compost pile was created using the windrow method. To increase the $\mathrm{C} / \mathrm{N}$ ratio in the composting materials, saw dust (particle size $10-20 \mathrm{~mm}$ ) from the local saw mill was added. These materials were spread in a compost pile $2 \mathrm{~m}$ wide at the base, $1 \mathrm{~m}$ high and $6 \mathrm{~m}$ long, with a total final volume of 10 $\mathrm{m}^{3}$. To avoid nutrient washout, the pile was set on an impermeable base and sheltered above. The proportion of fishwaste, cow dung and sawdust at 1:1:2 was well mixed. The total duration of the composting process was four months. The compost pile was turned weekly during the first two months and every 15 days during the last two months. The temperature and $\mathrm{O}_{2}$ levels were tested weekly to monitor the correct development of the process. Once the compost was considered mature, it was shifted using a $20 \mathrm{~mm}$ mesh screen and stored for further studies. The characteristics of fish waste compost are presented in Table. 2 .

\section{Evaluation of fish waste compost on black gram}

The effect of fishwaste compost on blackgram (Vigna mungo) variety KKM 1 was examined through a pot experiment during October - December 2019. The air-dried samples were used in the crop growth experiments. Each pot was filled with $15 \mathrm{~kg}$ of soils. The amendments such as RDF and different levels of $(0,1,2,3,4$, and $5 \mathrm{t} / \mathrm{ha})$ fish waste compost was mixed well with respective pots as per treatment plan. The recommended dose of fertilisers for black gram is 25: 50: 25 $\mathrm{kg}$ of $\mathrm{N}, \mathrm{P}_{2} \mathrm{O}_{5}$ and $\mathrm{K}_{2} \mathrm{O}$ per hectare. The pots were arranged in a completely randomized block design with three replication. After a week of equilibration, black gram (KKM1) seeds were sown. After establishment, a single healthy plant was allowed to grow in the pots. Soil samples were collected and analysed $\mathrm{pH}, \mathrm{EC}$, Organic carbon, Ammoniacal and nitrate nitrogen, available Phosphorus and available potassium at vegetative, flowering and harvest stages of the crop. Haulm and grain yield were recorded at the harvest stage of the crop.

\section{Statistical analysis}

The data obtained from the observations made in the various treatments of the experiments were statistically analysed as per the procedure given by Gomez and Gomez (1984) ${ }^{[11]}$. The analysis results were subjected to CRD and wherever the treatment variations were significant the critical difference was worked out at $5 \%$ probability $(\mathrm{P}=0.05)$. If the treatment differences were non-significant, it was denoted as NS.

\section{Results and Discussion}

The fish waste was acidic in $\mathrm{pH}$ (6.1) with EC of $3.8 \mathrm{dS} / \mathrm{m}$. The total N, P, K of the fish waste was $10.17,0.20$ and $0.79 \%$ respectively (Table.1). It also had an appreciable amount of organic carbon content $46.22 \%$. The calcium and magnesium content of fish waste were 1.86 and $0.15 \%$ respectively. Saw dust recorded the highest C:N ratio of 75:1. The total NPK content of the saw waste is very low. Some important characteristics of the fish waste compost are presented in Table 2. The results revealed that the compost was neutral in $\mathrm{pH}(7.1)$ with low soluble salts $(\mathrm{EC}=0.38 \mathrm{dS} / \mathrm{m})$. It has $28 \%$ organic carbon content and an appreciable amount of $\mathrm{N}$ $(1.6 \%), \mathrm{P}(0.16 \%)$ and $\mathrm{K}(0.21 \%)$.

Table 1: Characteristics of raw materials used for composting (on dry weight basis)

\begin{tabular}{|c|c|c|c|}
\hline S. No. & Parameters & Fish waste & Saw dust \\
\hline 1. & $\mathrm{pH}(1: 5)$ & $6.1 \pm 0.61$ & $7.5 \pm 0.75$ \\
\hline 2. & $\mathrm{EC}(1: 5)\left(\mathrm{dSm}^{-1}\right)$ & $3.8 \pm 0.38$ & $0.78 \pm 0.08$ \\
\hline 3. & C:N Ratio & $4.5 \pm 0.45$ & $75 \pm 7.50$ \\
\hline 4. & Organic carbon $(\%)$ & $46.2 \pm 4.62$ & $31.5 \pm 3.15$ \\
\hline 5. & Total Nitrogen (\%) & $10.17 \pm 1.02$ & $0.42 \pm 0.04$ \\
\hline 6. & Total Phosphorus (\%) & $0.2 \pm 0.02$ & $0.06 \pm 0.01$ \\
\hline 7. & Total Potassium (\%) & $0.79 \pm 0.08$ & $0.65 \pm 0.07$ \\
\hline 8. & Total Calcium (\%) & $1.86 \pm 0.19$ & $0.31 \pm 0.03$ \\
\hline 9. & Total Magnesium (\%) & $0.15 \pm 0.01$ & $0.29 \pm 0.03$ \\
\hline
\end{tabular}

Mean value \pm Standard deviation

Table 2: Characteristics of final harvested fish waste compost

\begin{tabular}{|c|c|c|}
\hline S. No. & Parameters & Fish waste compost (FWC) \\
\hline 1. & $\mathrm{pH}(1: 5)$ & $7.1 \pm 0.71$ \\
\hline 2. & EC $(1: 5)\left(\mathrm{dSm}^{-1}\right)$ & $0.38 \pm 0.04$ \\
\hline 3. & C:N Ratio & $17.1 \pm 2.80$ \\
\hline 4. & Organic carbon $(\%)$ & $28 \pm 0.16$ \\
\hline 5. & Total Nitrogen $(\%)$ & $1.6 \pm 0.02$ \\
\hline 6. & Total Phosphorus $(\%)$ & $0.16 \pm 0.02$ \\
\hline 7. & Total Potassium $(\%)$ & $0.21 \pm 1.71$ \\
\hline
\end{tabular}

Mean value \pm Standard deviation

\section{Effect on soil properties}

The soil was slightly alkaline in reaction both initial (pH-8.2) and post-harvest stage (pH-8.19). Application of FWC slightly decreased soil $\mathrm{pH}$, but this effect was statistically non-significant (Table 3). The decrease in acidity is because of release of mineral acids from fertilizer (Sedberry, 1971), release of organic acids from the decomposition of FWC (Saxena et al., 2001) and excretion of organic acid such as gluconic acid by the microbes (Sunithakumari et al., 2016). The soil EC was significantly affected by various treatments imposed. The highest EC $\left(0.27 \mathrm{dS} \mathrm{m}^{-1}\right)$ was observed in the soil receiving RDF + FWC $5 \mathrm{t} / \mathrm{ha}$. The control plot noticed for lowest EC $\left(0.21 \mathrm{dS} \mathrm{m}^{-1}\right)$ (Table 3$)$. The soil EC was low and safe level under all treatments imposed.

Table 3: Effect of fish waste compost (FWC) on soil reaction and electrical conductivity

\begin{tabular}{|c|c|c|c|c|c|c|}
\hline \multirow{2}{*}{ Treatment } & \multicolumn{3}{|c|}{ pH } & \multicolumn{3}{|c|}{$\mathrm{EC}\left(\mathrm{dS} \mathrm{m}^{-1}\right)$} \\
\hline & Vegetative & Flowering & Harvest & Vegetative & Flowering & Harvest \\
\hline RDF + FWC 0 t/ha & 8.21 & 8.21 & 8.21 & 0.22 & 0.22 & 0.21 \\
\hline RDF + FWC 1 t/ha & 8.21 & 8.20 & 8.20 & 0.22 & 0.21 & 0.21 \\
\hline RDF + FWC 2 t/ha & 8.22 & 8.20 & 8.20 & 0.23 & 0.22 & 0.21 \\
\hline RDF + FWC 3 t/ha & 8.20 & 8.20 & 8.19 & 0.24 & 0.22 & 0.19 \\
\hline RDF + FWC 4 t/ha & 8.24 & 8.23 & 8.23 & 0.27 & 0.25 & 0.23 \\
\hline RDF + FWC 5 t/ha & 8.20 & 8.19 & 8.19 & 0.25 & 0.23 & 0.22 \\
\hline Mean & 8.20 & 8.19 & 8.19 & 0.25 & 0.23 & 0.22 \\
\hline SEd & 0.27 & 0.30 & 0.30 & 0.009 & 0.01 & 0.01 \\
\hline $\mathrm{CD}(0.05)$ & NS & NS & NS & 0.019 & 0.02 & 0.02 \\
\hline
\end{tabular}


The soil organic carbon content was higher $(0.43 \%)$ in treatments receiving FWC $4 \mathrm{t} / \mathrm{ha}$ which was on par with treatment receiving FWC 3 t/ha at all the stages (Table 4).

Table 4: Effect of FWC on soil organic carbon status at different stages of black gram

\begin{tabular}{|c|c|c|c|}
\hline \multirow{2}{*}{ Treatment } & \multicolumn{3}{|c|}{ Organic carbon (\%) } \\
\cline { 2 - 4 } & Vegetative & Flowering & Harvest \\
\hline RDF + FWC 0 t/ha & 0.41 & 0.41 & 0.41 \\
\hline RDF + FWC 1 t/ha & 0.41 & 0.41 & 0.42 \\
\hline RDF + FWC 2 t/ha & 0.41 & 0.41 & 0.42 \\
\hline RDF + FWC 3 t/ha & 0.43 & 0.43 & 0.43 \\
\hline RDF + FWC 4 t/ha & 0.43 & 0.43 & 0.43 \\
\hline RDF + FWC 5 t/ha & 0.42 & 0.41 & 0.41 \\
\hline Mean & 0.42 & 0.42 & 0.43 \\
\hline SEd & 0.01 & 0.01 & 0.02 \\
\hline CD (0.05) & NS & NS & NS \\
\hline
\end{tabular}

\section{Ammoniacal\& Nitrate Nitrogen $\left(\mathrm{NH}_{4}-\mathrm{N} \& \mathrm{NO}_{3}-\mathrm{N}\right)$}

Various levels of application of FWC marked influence on soil ammoniacal \& nitrate nitrogen content. The soil $\mathrm{NH}_{4}-\mathrm{N}$ ranged from 130 to 144,125 to 140 and 109 to $125 \mathrm{kgha}^{-1}$ at vegetative, flowering and harvest stages respectively.

Application of FWC has influenced the $\mathrm{NO}_{3}-\mathrm{N}$ at different growth stages of black gram. It varied from 48 to 66,31 to 55 and 25 to $45 \mathrm{~kg} \mathrm{ha}^{-1}$ at vegetative, flowering and harvest stage respectively. Treatment receiving FWC @ 4 t/ha recorded highest value of both $\mathrm{NH}_{4}-\mathrm{N}$ and $\mathrm{NO}_{3}-\mathrm{N}$ at various stages of crop growth. (Table.5).
The decreasing trend was observed $\mathrm{inNH}_{4}-\mathrm{NandNO}_{3}-\mathrm{N}$ content. A gradual reduction was observed in nitrogen fraction as the crop growth advances. The removal of nutrients by the crop might be reason for this declining fertility. The earlier report of Abbadi and Gerendás (2015) also supported this finding. Besides this, the creation of favourable soil environment facilitated the nitrogen fixation by the soil microbes (Goyal et al., 1992). This result corroborates with the findings of Mangaladevi (2012) and Maurya et al., (2018).

Table 5: Effect of FWC on soil $\mathrm{NH}_{4}-\mathrm{N} \& \mathrm{NO}_{3}-\mathrm{N}$ status at different stages of black gram

\begin{tabular}{|c|c|c|c|c|c|c|}
\hline \multirow{2}{*}{ Treatment } & \multicolumn{3}{|c|}{$\mathbf{N H}_{\mathbf{4}} \mathbf{- N}\left(\mathbf{k g ~ h a}^{-\mathbf{1}}\right)$} & \multicolumn{3}{c|}{ NO $_{\mathbf{3}} \mathbf{N}\left(\mathbf{k g ~ h a} \mathbf{~}^{-1}\right)$} \\
\cline { 2 - 7 } & Vegetative & Flowering & Harvest & Vegetative & Flowering & Harvest \\
\hline RDF + FWC 0 t/ha & 98 & 95 & 88 & 45 & 31 & 28 \\
\hline RDF + FWC 1 t/ha & 101 & 96 & 95 & 48 & 36 & 25 \\
\hline RDF + FWC 2 t/ha & 105 & 98 & 96 & 55 & 38 & 36 \\
\hline RDF + FWC 3 t/ha & 120 & 116 & 106 & 60 & 46 & 38 \\
\hline RDF + FWC 4 t/ha & 144 & 140 & 125 & 64 & 54 & 45 \\
\hline RDF + FWC 5 t/ha & 130 & 125 & 106 & 66 & 55 & 44 \\
\hline Mean & 116 & 112 & 104 & 56 & 43 & 36 \\
\hline SEd & 8.05 & 7.33 & 6.69 & 2.26 & 2.37 & 1.38 \\
\hline CD (0.05) & 15.61 & 15.14 & 12.81 & 4.66 & 4.88 & 2.84 \\
\hline
\end{tabular}

\section{Available Phosphorus (Olsen-P)}

A significant difference on available $\mathrm{P}$ status of soil was observed due to various treatments. The mean $\mathrm{P}$ ranged from 15.00 to $19.79 \mathrm{~kg} \mathrm{ha}^{-1}$. The available $\mathrm{P}$ got increased over vegetative stages and decreased there with harvest stage of the crop. The minimum available $\mathrm{P}$ was documented without addition of FWC. In respect of available phosphorous in soil, phosphorous availability was increased wherever FWC was applied. (Manikandan and Subramanian, 2010)

Table 6: Effect of FWC on soil available phosphorus status at different stages of black gram

\begin{tabular}{|c|c|c|c|}
\hline \multirow{2}{*}{ Treatment } & \multicolumn{3}{|c|}{ Soil available P in $\left(\mathbf{k g ~ h a}^{-1}\right)$} \\
\cline { 2 - 4 } & Vegetative & Flowering & Harvest \\
\hline RDF + FWC 0 t/ha & 15.55 & 11.65 & 10.40 \\
\hline RDF + FWC 1 t/ha & 15.30 & 11.35 & 10.20 \\
\hline RDF + FWC 2 t/ha & 15.45 & 11.53 & 10.25 \\
\hline RDF + FWC 3 t/ha & 18.50 & 14.50 & 14.05 \\
\hline RDF + FWC 4 t/ha & 22.50 & 19.50 & 18.10 \\
\hline RDF + FWC 5 t/ha & 20.50 & 16.50 & 16.10 \\
\hline Mean & 19.79 & 16.09 & 15.00 \\
\hline SEd & 0.91 & 0.62 & 0.67 \\
\hline CD (0.05) & 1.88 & 1.27 & 1.39 \\
\hline
\end{tabular}

\section{Available Potassium ( $\left.\mathrm{NH}_{4} \mathrm{OAc}-\mathrm{K}\right)$}

Various dose of FWC significantly influenced the soil available potassium (Table 7). The soil available $\mathrm{K}$ ranged from 269 to $325 \mathrm{~kg} \mathrm{ha}^{-1}$ at various stages of crop growth due to the influence of different treatments. A gradual reduction in available potassium was observed as the crop growth advanced. 
Table 7: Effect of FWC on soil available potassium status at different stages of black gram

\begin{tabular}{|c|c|c|c|}
\hline \multirow{2}{*}{ Treatment } & \multicolumn{3}{|c|}{ Soil available K (kg ha-1) } \\
\cline { 2 - 4 } & Vegetative & Flowering & Harvest \\
\hline RDF + FWC 0 t/ha & 281 & 275 & 270 \\
\hline RDF + FWC 1 t/ha & 282 & 275 & 269 \\
\hline RDF + FWC 2 t/ha & 282 & 275 & 269 \\
\hline RDF + FWC 3 t/ha & 301 & 296 & 291 \\
\hline RDF + FWC 4 t/ha & 325 & 318 & 311 \\
\hline RDF + FWC 5 t/ha & 290 & 284 & 279 \\
\hline Mean & 304 & 297 & 292 \\
\hline SEd & 7.29 & 5.71 & 10.71 \\
\hline CD (0.05) & 15.00 & 11.73 & 22.03 \\
\hline
\end{tabular}

The soil available potassium increased at vegetative, flowering and harvest stage of black gram due to the addition of RDF along with FWC. Decreasing trend is observed in soil available $\mathrm{K}$ from vegetative to harvest stage, this might be due to the crop removal. The similar results are reported by (Dhar et al., 2009; Chaudhar, 2017).

\section{Effect on crop}

The grain yield of black gram significantly increased due to the application of FWC. The data pertaining to the grain yield (Fig. 1) revealed that grain yield obtained from various treatments ranged from 2.18 to $3.02 \mathrm{~g} /$ plant.

With respect to various treatments, the highest grain yield of $3.02 \mathrm{~g} /$ plantwas accounted for RDF + FWC @ $4 \mathrm{t} / \mathrm{ha}$ followed by RDF + FWC @ 5 t/ha $\left(2.67\right.$ g plant $\left.^{-1}\right)$. The minimum yield was documented with the control $\left(2.18 \mathrm{~g} \mathrm{plant}^{-1}\right)$. The higher grain yield was due to carbohydrate synthesis and translocation of sugars; healthy photosynthesis of crops, phytohormone production of root associated microbes and NPK fertilization. Malewar et al., (1990) ${ }^{[16]}$ and Kumar et al., (2004) [17] reported similar findings in mungbean and turmeric.

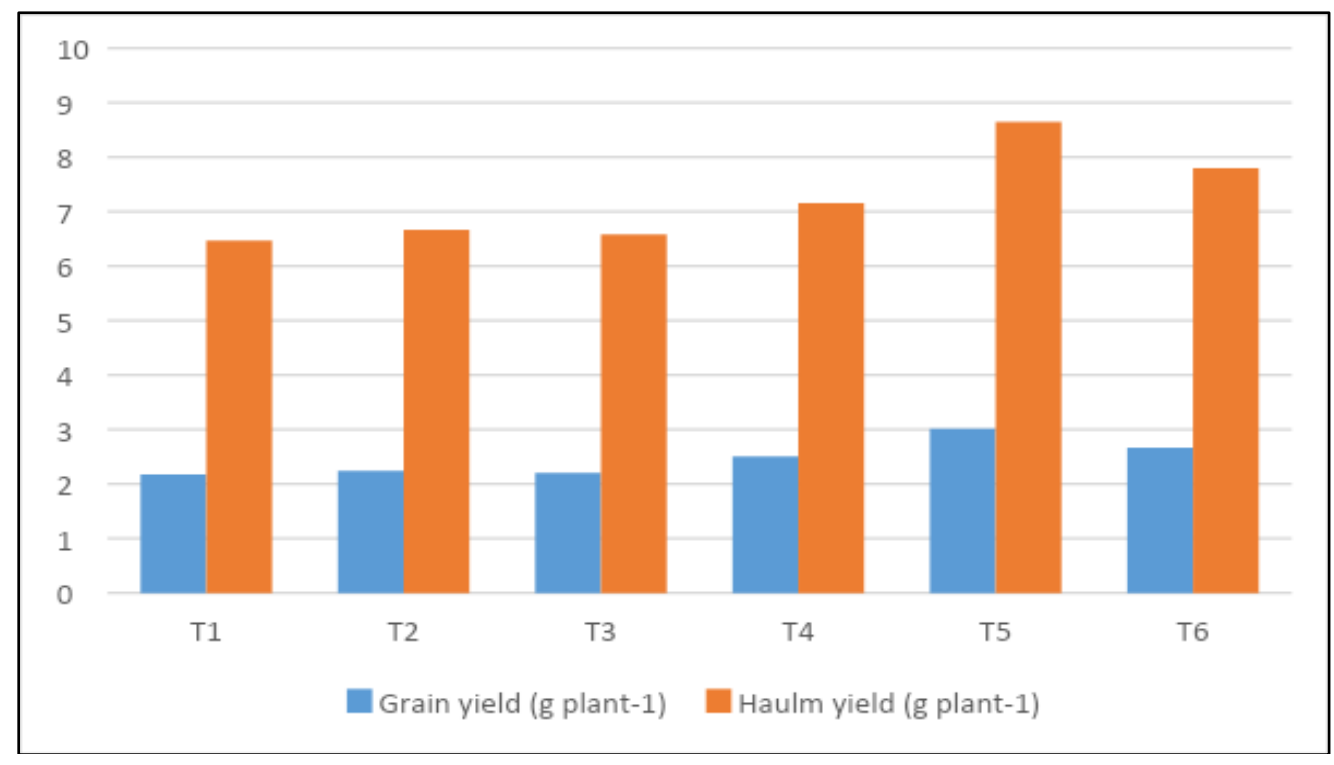

Fig 1: Effect of FWC on grain and haulm yields

The combined application of RDF and FWC significantly increased the haulm yield of black gram (Fig.1). The haulm yield varied from 6.47 to $8.65 \mathrm{~g} /$ plant. The maximum haulm yield of $8.65 \mathrm{~g} /$ plant recorded in RDF + FWC @ $4 \mathrm{t} / \mathrm{ha}$. The lowest haulm yield was recorded in control with $6.47 \mathrm{~g} / \mathrm{plant}$. The higher haulm yield was due to the increased plant height, plant biomass, shoot and root length influenced by plant growth promoters like IAA, GA and also through inorganic fertilization Newaj et al., (2002) ${ }^{[18]}$ and El Karamany et al., (2019) ${ }^{[19]}$.

\section{Conclusion}

Disposal of solid waste generated from seafood processing plants has always been a problem for seafood processors. The inappropriate disposal of solid fish wastes may result in environmental problems, such as groundwater and surface water pollution through the leaching due to its high nutritive content. These wastes could be converted into eco-friendly compost through a bioconversion process. Composting of fish waste is a relatively new, practical and an environmentally sound alternative to fish waste disposal. It is economical, fairly odourless and a biologically beneficial practice for seafood operations. In the crop growth studies, distinct increase in grain and haulm yield of black gram and soil fertility was observed indicating a good out of waste practice.

\section{References}

1. Chand S, Anwar M, Patra DD. Influence of long-term application of organic and inorganic fertilizer to build up soil fertility and nutrient uptake in mint-mustard cropping sequence. Commun. Soil Sci. Plant Anal. 2006; 37:63-76.

2. Egan H, Krik RS, Sawyer R. Pearsons' chemical analysis of foods. 9th ed., Longman, London, 1997, 634.

3. Kinnunen RE, Gould MC, Cambier P. Composting commercial fish processing waste from fish caught in the Michigan waters of the Great Lakes, Michigan State University Extension, USA, 2005

4. Shewry PR, Halford NG. Cereal seed storage proteins: structures, properties and role in grain utilization. $\mathrm{J}$ of Exp. Bot. 2002; 53(370):947-958.

5. Amruta N, Maruthi J, Sarika G, Deepika C. Effect of integrated nutrient management and spacing on growth and yield parameters of black gram cv. LBG-625 (Rashmi). The Bioscan. 2015; 10(1):193-198

6. Archana D, Nandish M, Savalagi V, Alagawadi A. Characterization of potassium solubilizing bacteria (KSB) from rhizosphere soil Bioinfolet-A Quarterly J. of Life Sci. 2013; 10(1b):248-257.

7. Marimuthu S, Surendran U. Effect of nutrients and plant growth regulators on growth and yield of black gram in 
sandy loam soils of Cauvery new delta zone, Ind. Cogent Food \& Agric. 2015; 1(1):1010415.

8. Vidyashree $\mathrm{N}$. Isolation and characterization of zinc solubilizing bacteria from stone quarry dust powder." Int. J of Agric. Sci.s, ISSN:0975-3710, 2016.

9. Ramesh A, Sharma SK, Sharma MP, Yadav N, Joshi OP. Inoculation of zinc solubilizing Bacillus aryabhattai strains for improved growth, mobilization and biofortification of zinc in soybean and wheat cultivated in Vertisols of central India. Applied Soil Ecol. 2014; 73:87-96.

10. Goteti PK, Emmanuel LDA, Desai S, Shaik MHA. Prospective zinc solubilising bacteria for enhanced nutrient uptake and growth promotion in maize (Zea mays L.). Int. J of Microbiol. 2013.

11. Gomez KA, Gomez AA. Statistical procedures for agricultural research: John Wiley \& Sons, 1984.

12. Khande R, Sharma SK, Ramesh A, Sharma MP. Zinc solubilizing Bacillus strains that modulate growth, yield and zinc biofortification of soybean and wheat. Rhizosphere. 2017; 4:126-138.

13. Navsare R, Mane S, Supekar S. Effect of potassium and zinc solubilizing microorganism on growth, yield and quality of mungbean IJCS. 2018; 6(1):1996-2000.

14. Raut A, Durgude A, Kadlag A. Effect of zinc solubilizing bacteria on zinc use efficiency and yield of summer groundnut grown in Entisol. IJCS. 2019; 7(1):17101713.

15. Selvakumar G, Reetha S, Thamizhiniyan P. Response of biofertilizers on growth, yield attributes and associated protein profiling changes of blackgram (Vigna mungo L. Hepper). World applied Sci.s J. 2012; 16(10):1368-1374.

16. Malewar G, Mangnale M, Malewar V. Chemical composition and quality of mung genotypes as influenced by zinc fertilization. Legume Research 1990; 13(2):5964.

17. Kumar PS, Geetha SA, Savithri P, Jagadeeswaran R, Ragunath K. Effect of $\mathrm{Zn}$ enriched organic manures and zinc solubilizer application on the yield, curcumin content and nutrient status of soil under turmeric cultivation. J of Applied Hortic. 2004; 6(2):82-86

18. Newaj M, Hossain MS, Islam MN, Anam M, Haque A. Effect of Indoleacetic Acid (IAA) on Yield of Mungbean (Vigna radiata L.). Pak. J of Biol. Sci 2002; 5:897-899.

19. El Karamany MF, Sadak MS, Bakry BA. Improving quality and quantity of mungbean plant via foliar application of plant growth regulators in sandy soil conditions. Bulletin of the National Res. Centre. 2019; 43(1):61. 